\title{
DESIGN AND ANALYSIS OF HELIUM BRAYTON CYCLE FOR ENERGY CONVERSION SYSTEM OF RGTT200K
}

\author{
Ignatius Djoko Irianto \\ Center for Nuclear Reactor Technology and Safety, National Nuclear Energy Agency \\ Puspiptek Area, Serpong,Tangerang 15310, Indonesia \\ E-mail: igndjoko@batan.go.id \\ Diterima editor : 18 Desember 2015 \\ Diperbaiki : 21 Juni 2016 \\ Disetujui untuk publikasi : 22 Juni 2016
}

\begin{abstract}
DESIGN AND ANALYSIS OF HELIUM BRAYTON CYCLE FOR ENERGY CONVERSION SYSTEM OF RGTT200K. The helium Brayton cycle for the design of cogeneration energy conversion system for RGTT200K have been analyzed to obtain the higher thermal efficiency and energy utilization factor. The aim of this research is to analyze the potential of the helium Brayton cycle to be implemented in the design of cogeneration energy conversion system of RGTT200K. Three configuration models of cogeneration energy conversion systems have been investigated. In the first configuration model, an intermediate heat exchanger (IHX) is installed in series with the gas turbine, while in the second configuration model, IHX and gas turbines are installed in parallel. The third configuration model is similar to the first configuration, but with two compressors. Performance analysis of Brayton cycle used for cogeneration energy conversion system of RGTT200K has been done by simulating and calculating using CHEMCAD code. The simulation result shows that the three configuration models of cogeneration energy conversion system give the temperature of thermal energy in the secondary side of IHX more than $800{ }^{\circ} \mathrm{C}$ at the reactor coolant mass flow rate of $145 \mathrm{~kg} / \mathrm{s}$. Nevertheless, the performance parameters, which include thermal efficiency and energy utilization factor (EUF), are different for each configuration model. By comparing the performance parameter in the three configurations of helium Brayton cycle for cogeneration energy conversion systems RGTT200K, it is found that the energy conversion system with a first configuration has the highest thermal efficiency and energy utilization factor (EUF). Thermal efficiency and energy utilization factor for the first configuration of the reactor coolant mass flow rate of $145 \mathrm{~kg} / \mathrm{s}$ are $35.82 \%$ and $80.63 \%$.
\end{abstract}

Keywords: Helium Brayton cycle, RGTT200K, Energy conversion system, EUF, Efficiency,

\section{ABSTRAK}

ANALISIS DAN DESAIN SIKLUS BRAYTON HELIUM UNTUK SISTEM KONVERSI ENERGI RGTT200K. Telah dilakukan analisis siklus Brayton helium pada desain sistem konversi energi kogenerasi RGTT200K untuk memperoleh tingkat efisiensi termal dan faktor pemanfaatan energi yang tinggi. Tujuan penelitian ini adalah untuk menganalisis potensi siklus Brayton helium untuk diterapkan dalam desain sistem konversi energi kogenerasi RGTT200K. Tiga model konfigurasi desain sistem konversi energi kogenerasi telah dianalisis. Pada model konfigurasi pertama Intermediate Heat Exchanger (IHX) dipasang secara serial dengan turbin gas, sedangkan pada model konfigurasi kedua IHX dan turbin gas dipasang secara paralel. Model konfigurasi ketiga mirip dengan konfigurasi pertama, tetapi pada model konfigurasi ketiga dipasang dua kompresor. Analisis kinerja pada desain siklus Brayton untuk sistem konversi energi RGTT200K dilakukan dengan cara simulasi dan perhitungan kinerja sistem konversi energi menggunakan kode komputer CHEMCAD. Hasil simulasi menunjukkan bahwa ketiga model konfigurasi dapat memberikan energi termal pada sisi sekunder IHX dengan temperatur lebih dari $800{ }^{\circ} \mathrm{C}$ jika laju aliran massa pendingin reaktor $145 \mathrm{~kg} / \mathrm{s}$. Namun demikian, paremeter kinerja yang meliputi efisiensi thermal dan faktor pemanfaatan energi (EUF) berbeda untuk masing-masing model konfigurasi. Hasil perbandingan parameter kinerja pada ketiga model konfigurasi siklus Brayton helium untuk sistem konversi energi kogenerasi RGTT200K menunjukkan bahwa model konfigurasi sistem konversi energi kogenerasi yang pertama memiliki efisiensi termal dan faktor pemanfaatan energi (EUF) tertinggi. Nilai efisiensi termal dan faktor pemanfaatan energi untuk model konfigurasi pertama dengan laju aliran massa pendingin reaktor $145 \mathrm{~kg} / \mathrm{s}$ adalah $35,82 \%$ dan $80,63 \%$.

Kata kunci: Siklus Brayton helium, RGTT200K, Sistem konversi energi, EUF, Efisiensi 


\section{INTRODUCTION}

The combination of all primary energy sources with fossil fuels and renewable energy will dominate the energy supply in the future. Due to the energy reserves of fossil fuels, dwindling the energy supply comes from nuclear energy is expected to take an increasingly large role [1]. The increasing role of nuclear energy as an energy supplier in the world is affected by the results of the research and development of reactor technology. The tendency of research and development activities on reactor technology in the world today is the development of energy systems based on Generation IV (Gen IV) reactors [2]. Nuclear energy system, which is currently being developed within the framework of the reactor Generation IV, is designed to offer passive and inherent safety to reduce the consequences of a nuclear accident $[1,2]$.

Reactor technology development, especially Generation IV reactors, is not only to be electricity generation but also to be a provider of thermal energy for industrial processes. Therefore, nuclear energy is not only used for a Nuclear Power Plant (NPP) but also for a Nuclear Energy Systems (NES) or a hybrid reactor system [3,4]. NES is a nuclear reactor, which implements a cogeneration configuration to generate electricity, hydrogen production and desalination process [3-5]. There are several design concepts of Generation IV reactor systems that implement cogeneration systems. Taking into account the outlet temperature of the reactor system and thermal efficiency for the hydrogen gas production process, the type of reactor that best matches the concept of cogeneration for power generation and the production of hydrogen gas is the concept of high-temperature gas-cooled reactor system (HTGR) [3-5].

Various studies related to the HTGR cogeneration system have been carried out. Gustavo Alonso et al. [6] reported that the cogeneration system of the Pebble Bed Modular Reactor (PBMR) can generate electricity and supply a process heat in refineries for the production of gasoline. The cogeneration system GTHTR300C can be used as power generation, hydrogen production and desalination of sea water [5,6]. GTHTR300C and PBMR cogeneration system are designed in a closed Brayton cycle [5,6]. In addition to the implementation of cogeneration systems in the Brayton cycle, the application of cogeneration system in the Rankine cycle has also been carried out [7]. Colin F. McDonald [8] proposed a power conversion system (PCS) in the combined cycle between Brayton cycle and a steam Rankine cycle. Another study by Po-Jui Li [9], by integrating Organic Rankine Cycle (ORC) and Brayton cycle with VHTR, the total efficiency of the PCS can be increased up to about $8.6 \%$.

This work is conducted to the design of energy conversion systems on RGTT200K with cogeneration purposes. RGTT200K is the conceptual design of High Temperature Gas-cooled Reactor (HTGR) that has been developed by BATAN. The development of RGTT200K is based on the analysis of energy supply needs in the Bangka Belitung island which is the result of a study from the Center for Energy Development - BATAN 2010 [10,11]. RGTT200K is also designed in the concept cogeneration. Utilization of the thermal energy from RGTT200K designed is for electricity generation, production of hydrogen gas and for seawater desalination. Energy conversion system on RGTT200K is designed using helium gas as the cooling fluid with the reactor outlet temperature $950{ }^{\circ} \mathrm{C}$ and the pressure $5 \mathrm{MPa}$.

The optimal design of RGTT200K energy conversion systems can be done by analyzing the performance of the systems and selecting one of the three alternative configuration models. In the first configuration model, an intermediate heat exchanger (IHX) is serially installed with the gas turbine, while in the second configuration model, IHX and gas turbines installed in parallel. The third configuration model is similar to the first configuration model, but installed with two compressors. Optimization of cogeneration energy conversion systems of RGTT200K are based on the analysis results from various configuration models of cogeneration energy conversion systems, the conceptual design of system components and the calculation results of performance parameters. Some performance parameters of the cogeneration energy conversion systems under consideration include the amount of thermal power that can be supplied to the unit utilization of thermal energy, thermal efficiency, and energy utilization factor (EUF) $[12,13]$. Thermal efficiency is calculated based on the ability of the energy conversion system for generating electricity while the EUF is calculated based on the total units of thermal energy utilization. 
The purpose of this research is to find the optimal configuration from the three alternative configuration modelss of energy conversion systems on RGTT200K cogeneration. Optimization calculation is based on two performance parameters, namely the thermal efficiency and EUF $[12,13]$. The conceptual design of cogeneration energy conversion systems of RGTT200K apply Brayton cycle. Calculation and modeling of thermodynamic processes of RGTT200K energy conversion systems are performed using computer software CHEMCAD. CHEMCAD software has been widely used in the modeling and simulation of cogeneration energy conversion systems [14-16].

\section{THEORY}

The thermal efficiency $(\eta)$ in energy conversion systems is defined as only the efficiency of thermal power for electricity generation. The overall values of thermal efficiency are the result of the division amongst the thermal power for electricity generations. The amount of thermal efficiency can be calculated using (1) [12].

$$
\eta=\frac{\Sigma W_{T}-\Sigma W_{C}-W_{S}}{Q_{t h}}
$$

where $\eta$ is thermal efficiency, $\Sigma W_{T}$ is the workload for turbine, $\Sigma W_{C}$ is the workload for compressor, $\Sigma W_{S}$ is the workload all system, and $Q_{t h}$ is the thermal power generated by the reactor.

The value of thermal energy utilization factor (EUF) which describes the amount of thermal energy that can be harnessed is calculated for each unit utilization as shown in equation (4) [11]. EUF value gives an overview of how the percentage of thermal energy that can be utilized.

$$
E U F=\frac{W+Q_{u}}{Q_{i n}} \times 100 \%
$$

where $E U F$ is the energy utilization factor, $W$ is the work produced by the cogeneration systems for power generation, $Q_{u}$ is the thermal power that is used in addition to power generation in cogeneration systems, and $Q_{i n}$ is the total power supplied to the cogeneration system.

\section{METHODOLOGY}

There are three units in the application of cogeneration energy conversion systems design RGTT200K, namely: applications for hydrogen gas production, applications for electricity generation and applications for seawater desalination. The source of thermal energy in the energy conversion system is a high- temperature gas-cooled reactor (HTGR) with the thermal power of $200 \mathrm{MW}$. The coolant temperature at the outlet of reactor is $950{ }^{\circ} \mathrm{C}$ and the pressure of the reactor coolant out of the reactor is $5 \mathrm{MPa}$.

Three alternative configurations are considered in the design of RGTT200K energy conversion systems. In the first configuration, as shown in Figure 1, helium gas as the reactor coolant flows from the reactor through IHX, gas turbines, recuperator, precooler, compressors, recuperator and returned to the reactor. Thermal power for the production of hydrogen gas are transferred from IHX at the secondary side and the thermal power for desalination are transferred from the precooler. The main component parameter values as input for simulations using CHEMCAD is shown in Table 1. Pressure drop in the shell side of heat exchanger is $0.04 \mathrm{Mpa}$. The heat transfer area and the total heat transfer coefficient on the heat exchanger are set to give the most effective heat exchanger. Simulation for energy conversion system configuration is done by setting the first three reactor operating parameters, i.e. temperature, pressure and power of the reactor thermal. Thermal power of the reactor was set to $200 \mathrm{MWt}$, coolant pressure at the point of reactor coolant output was set to 5.0 MPa. Simulations are carried out by varying the coolant mass flow rate from $100 \mathrm{~kg} / \mathrm{s}$ to $200 \mathrm{~kg} / \mathrm{s}$.

The second alternative configuration of RGTT200K energy conversion system is shown in Figure 2. The difference between the first and the second configuration is the addition of flow divider 
that is mounted to the cooling channel out of the reactor. The function of flow divider is to divide the flow of coolant coming out from the reactor into the gas turbine to supply thermal power for electricity generation and the flow to IHX for the production of hydrogen gas. The amount distribution of the flow in the flow divider can be adjusted according to the needs. In this case, flow is divided respectively by $50 \%$ to the turbine and to IHX. The main component parameters are shown in Table 1 .

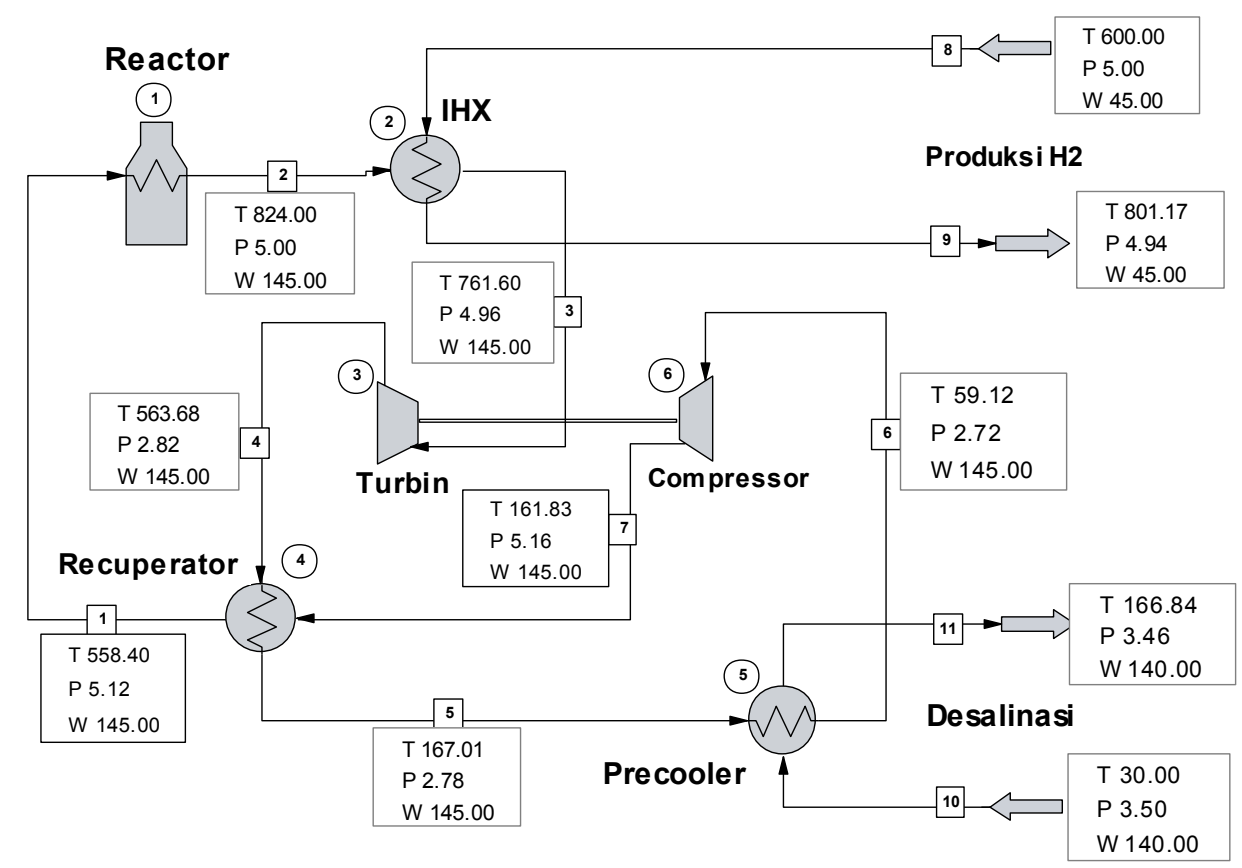

Figure 1. Flowsheet of the first configuration of RGTT200K energy conversion systems.

Table 1. The Component parameters of RGTT200K energy conversion systems.

\begin{tabular}{ll}
\hline Parameters & Value \\
\hline Pressure drop in the reactor & $0.120 \mathrm{MPa}$ \\
Pressure drop in the shell side of IHX & $0.040 \mathrm{MPa}$ \\
Pressure drop in the tube side of IHX & $0.060 \mathrm{MPa}$ \\
The heat transfer area (A) of IHX & $1448 \mathrm{~m}^{2}$ \\
The total heat transfer coefficient (U) of IHX & $458 \mathrm{~W} / \mathrm{m}^{2} . \mathrm{K}$ \\
The polytropic efficiency of gas turbine & 0.950 \\
The polytropic efficiency of compressor & 0.950 \\
Pressure drop on the hot side of recuperator & $0.040 \mathrm{MPa}$ \\
Pressure drop on the cold side of recuperator & $0.040 \mathrm{MPa}$ \\
The U A factor of recuperator & $92.674 \mathrm{MW} / \mathrm{K}$ \\
Pressure drop in the shell side of precooler & $0.040 \mathrm{MPa}$ \\
Pressure drop in the tube side of precooler & $0.060 \mathrm{MPa}$ \\
The heat transfer area (A) of precooler & $1448 \mathrm{~m}^{2}$ \\
\hline
\end{tabular}




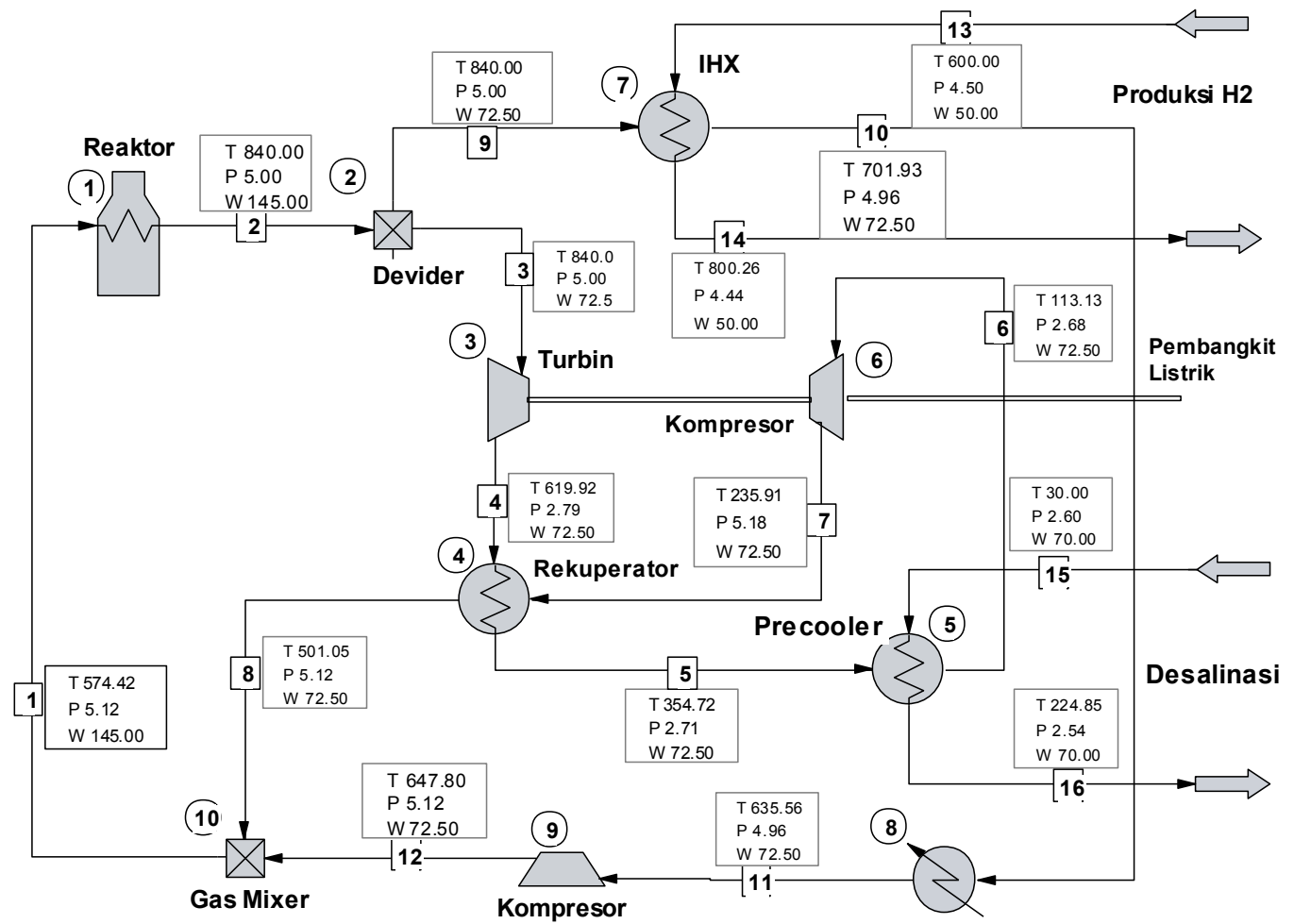

Figure 2. Flowsheet of the second configuration of RGTT200K energy conversion systems.

Theoretically, two compressors and one intercooler in the middle can increase the thermal efficiency of energy conversion system. In the third configuration, two compressors and one intercooler are installed to obtain higher thermal efficiency as shown in Figure 3. In this model, two compressors are mounted, i.e. High-Pressure Compressor (HPC) and Low-Pressure Compressor (LPC). HPC and LPC compressor are fitted with the same characteristics while the intercooler is fitted with the same characteristics as in the pre-cooler. The input for this model is also shown in Table 1.

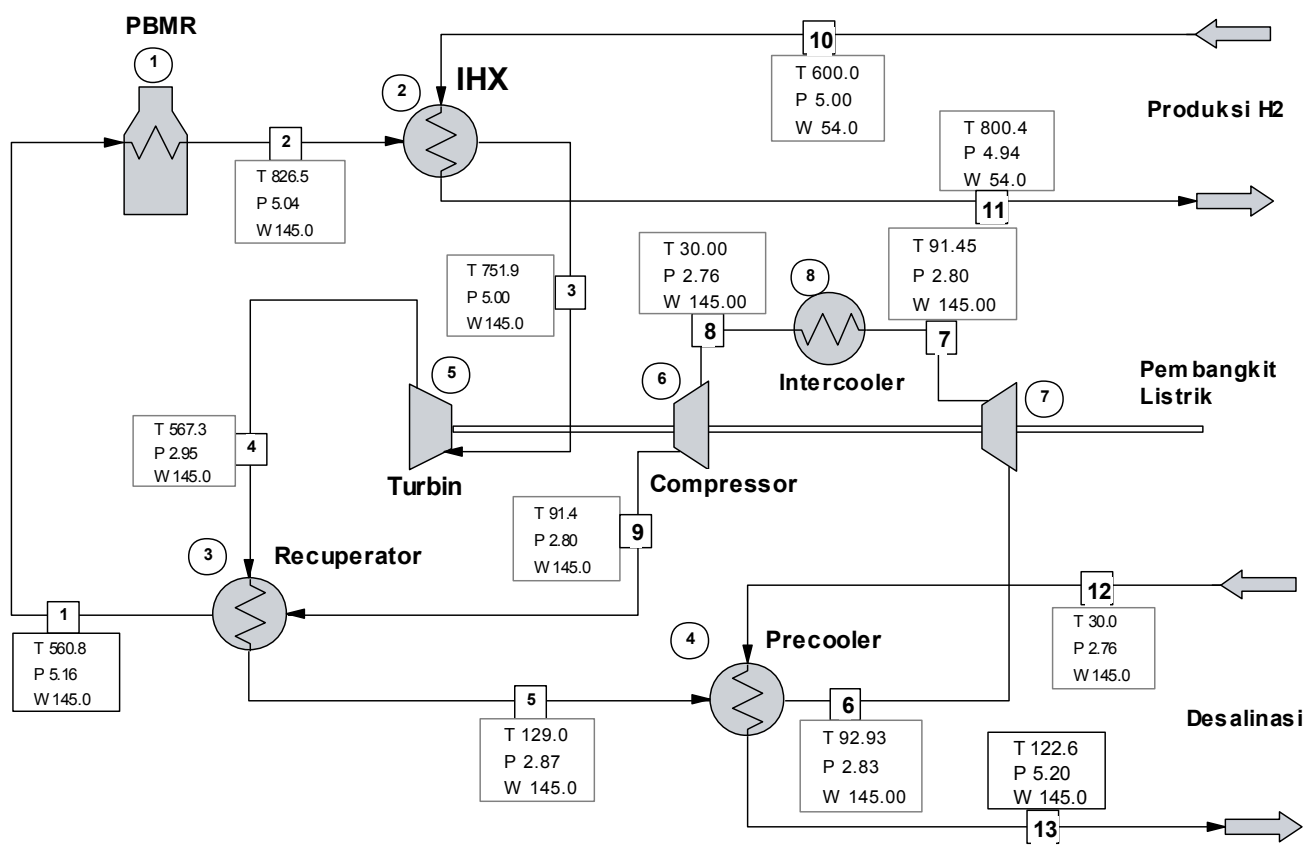

Figure 3. Flowsheet of the third configuration of RGTT200K energy conversion systems. 


\section{RESULTS AND DISCUSSION}

The simulation results using CHEMCAD on the three configurations model of helium Brayton cycle for RGTT200K cogeneration energy conversion systems are shown in Figures $4-6$. The simulations are carried out by raising the reactor coolant mass flow rate from $100 \mathrm{~kg} / \mathrm{s}$ to $200 \mathrm{~kg} / \mathrm{s}$. The simulation results shown that the addition of reactor coolant mass flow rate will decrease the coolant temperature coming out from the reactor. Decrease in coolant temperature out of the reactor results in the decreased of coolant temperature through IHX on the secondary side which is used as a supplier of heat energy for the production of hydrogen gas. As shown in Figures $4-6$, an increase in the mass flow rate of the reactor coolant resulted in a decrease in the coolant temperature out of the reactor. The reactor can supply thermal energy at temperatures sufficient for hydrogen production; the increased mass flow rate of the reactor coolant should be limited. Therefore, the mass flow rate of reactor coolant is limited by the temperature which can still be supplied by an energy conversion system through IHX to the installation of hydrogen production. If the installation of hydrogen production using the iodinesulfur cycle process (IS cycle), the minimum temperature which are required for the production of hydrogen gas through the IHX is $850^{\circ} \mathrm{C}$ [17]. However, if steam methane reforming method is used, the temperature required for the production of hydrogen gas can be lower, at a temperature of $800{ }^{\circ} \mathrm{C}$ $[18,19]$. The temperature of $800{ }^{\circ} \mathrm{C}$ is the temperature required to decompose methane (CH4) into carbon monoxide gas and hydrogen gas. Therefore, the installation of hydrogen gas production can be operated the coolant temperature of the secondary side of IHX should be not less than $800{ }^{\circ} \mathrm{C}$.

The simulation is done by varying the mass flow rate of reactor coolant from $100 \mathrm{~kg} / \mathrm{s}$ to 200 $\mathrm{kg} / \mathrm{s}$ for the three design configurations of energy conversion systems of RGTT200K to show some different characteristics. As shown in Figures 4-6, the first, the second and the third configuration design of helium Brayton cycle for energy conversion system of RGTT200K give the temperature of thermal energy at the secondary side of IHX more than $800{ }^{\circ} \mathrm{C}$ of each at the reactor coolant mass flow rate about $145 \mathrm{~kg} / \mathrm{s}$. In accordance with equation (1), (2) and (3) that the decrease in temperature at the hot side of heat exchanger results in a decrease of the temperature in thermal power transferred through IHX at the secondary side or cold side of the exchanger.

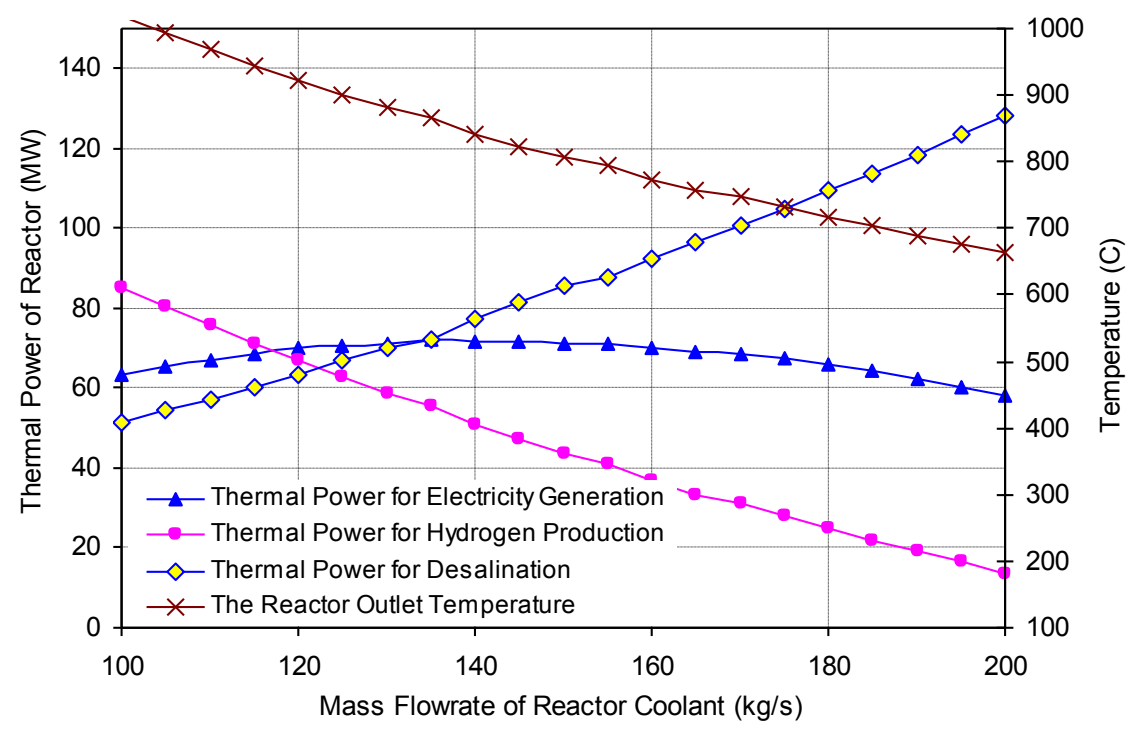

Figure 4. Thermal power distribution on each unit as a function of the reactor coolant mass flow rate in the first configuration. 


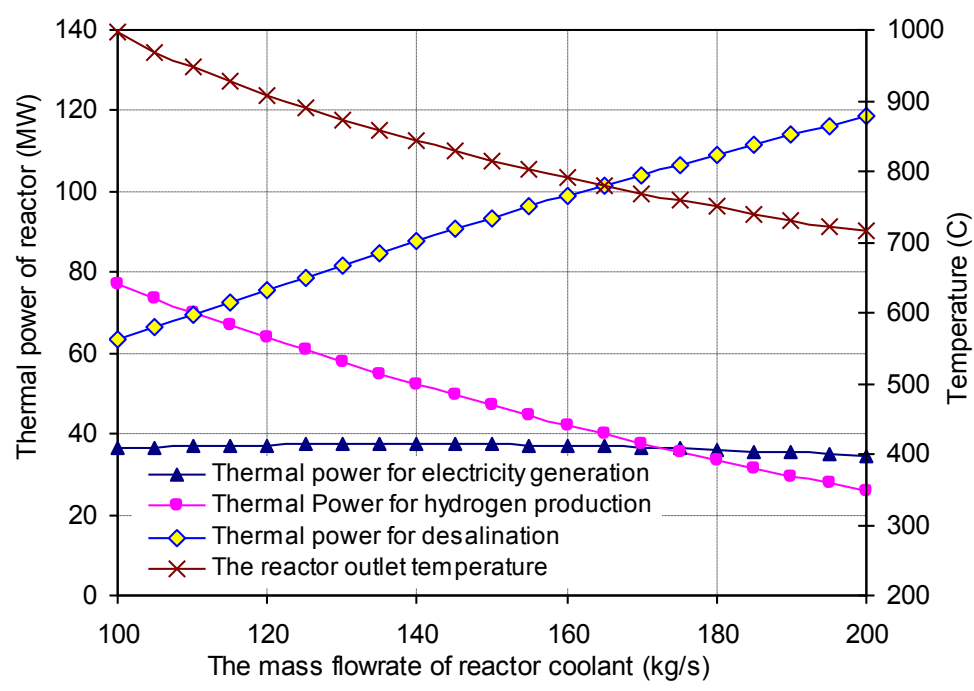

Figure 5. Thermal power distribution on each unit as a function of the reactor coolant mass flow rate in the second configuration.

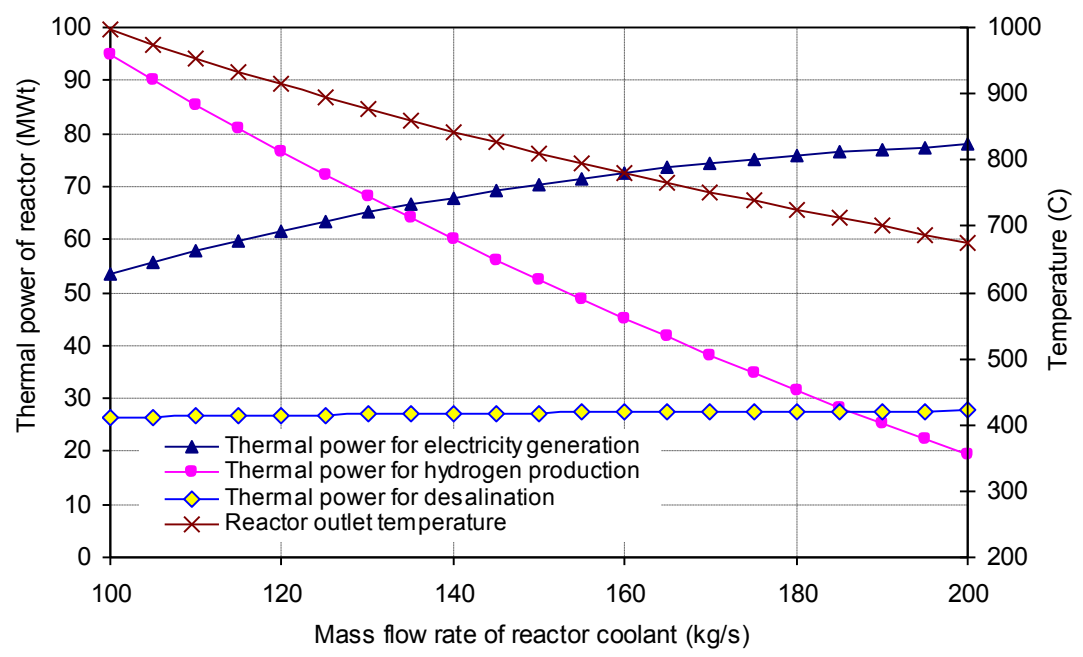

Figure 6. Thermal power distribution on each unit as a function of the reactor coolant mass flow rate in the first configuration.

Figure 4 and Figure 5 show that the thermal power for electricity generation will rise by increasing the reactor coolant mass flow rate until $145 \mathrm{~kg} / \mathrm{s}$ after that the thermal power for electricity generation will decrease. The addition of the reactor coolant mass flow rate also increases the thermal power, which is supplied to the turbine to be converted into mechanical energy. Increasing of the thermal power which be supplied to the turbine will be accompanied by rising thermal power that required rotating the compressor. The thermal power for electricity generation represents is the difference between the thermal power which be supplied to the turbine and the thermal power which be required to rotate the compressor. In the third configuration in which there are two compressors, as shown in Figure 6, showed a different trend. In the third configuration, the thermal power for electricity generation continues to increase with the addition of the reactor coolant mass flow rate, but the thermal power for hydrogen production decreases. Thus, the third configuration is most suitable when the utilization of thermal energy from an energy conversion system is an electricity generation.

Referring to the simulation for the first configuration results showed that the highest increase in thermal power for electricity generation will be achieved on the cooling mass flow rate $145 \mathrm{~kg} / \mathrm{s}$. In the coolant mass flow rate $145 \mathrm{~kg} / \mathrm{s}$, the thermal power for electricity generation of the first configuration is $71.66 \mathrm{MWt}$, the second configuration is $37.39 \mathrm{MWt}$ and the third configuration is $69.24 \mathrm{MWt}$. 
In contrast to the thermal power used for electricity generation, the thermal power supplied from the precooler for the desalination process continues to increase with the addition of the mass flow rate of the coolant. This can be explained using the equation (3) that the addition of coolant mass flow rate will increase the rate of heat transfer in the heat exchanger. Instead, the thermal power that is used for the production of hydrogen which is transferred by IHX decreased with increasing mass flow rate of the reactor coolant. The decline in the thermal power transferred by IHX caused by decreasing the temperature of coolant out of the reactor. This is in accordance with equation (3) which indicates that the thermal power transferred by the heat exchanger is proportional to the temperature difference.

From the results of these calculations, for the first configuration, the mass flow rate of reactor coolant that can be considered is equal to $145 \mathrm{~kg} / \mathrm{s}$. With the mass flow rate of the reactor coolant 145 $\mathrm{kg} / \mathrm{s}$, the temperature of coolant out of the reactor $801{ }^{\circ} \mathrm{C}$, thermal power transferred through to the production of hydrogen gas IHX $47.02 \mathrm{MW}$, thermal power is transferred through the precooler for desalination $81.35 \mathrm{MW}$ and thermal power for $71.66 \mathrm{MW}$ electricity generation.

The difference between the first configuration and the second configuration is the installation of flow divider (flow divider) on the side of the coolant channel out of the reactor and installation of the compressor in the cooling channel out of IHX. Installation of the compressor is intended to enable the corresponding flow as regulated by flow divider. This is required to drive the compressor power from outside the system, so the power is going into the system is thermal power reactors and propulsion power compressor number 9 in Figure 2. The amount of power driving the compressor is varied equivalent to the mass flow rate of coolant flowing through IHX expected. In this simulation of the driving force equivalent to $3.07 \mathrm{MWt}$ compressor for a reactor coolant mass flow rate of $100 \mathrm{~kg} / \mathrm{s}$ and is equivalent to $6.27 \mathrm{MWt}$ for a reactor coolant mass flow rate of $200 \mathrm{~kg} / \mathrm{s}$.

As in the previous simulation, the simulation for the second configuration is also done with a variant of the mass flow rate of the coolant of $100 \mathrm{~kg} / \mathrm{s}$ up to $200 \mathrm{~kg} / \mathrm{s}$. The simulation of thermal power reactors and reactor coolant pressure out of the same set, the reactor power of $200 \mathrm{MWt}$ and the pressure remains at 5.0 MPa. The power distribution of the second configuration of energy conversion system RGTT200K by using CHEMCAD shown in Figure 5 and the power distribution of the third configuration shown in Figure 6.

Figure 7, Figure 8, and Figure 9 show a comparison of the performance of the three configurations of energy conversion systems for electricity generation, hydrogen production, and desalination process. For the first configuration is shown good performance for the generation of electricity, especially in the coolant mass flow rate of $145 \mathrm{~kg} / \mathrm{s}$, which amounted to $71.66 \mathrm{MWt}$. In the third configuration, although the thermal power for electricity generation increased by the addition of the coolant mass flow rate, the thermal power for the production of hydrogen gas and for the desalination process is lower.

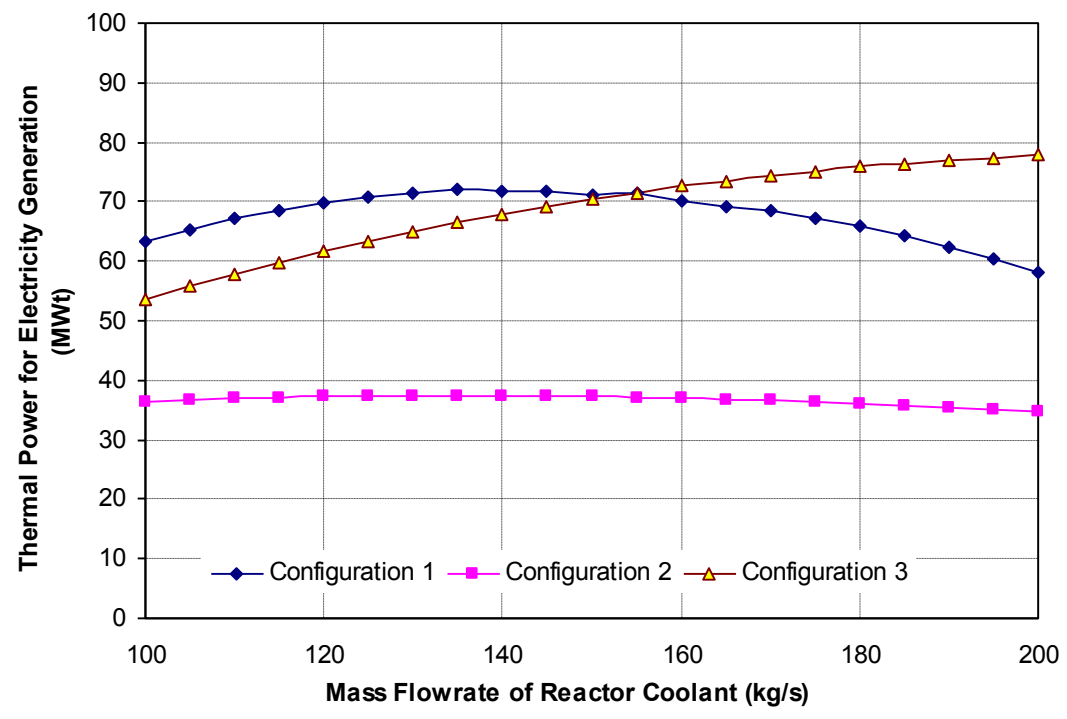

Figure 7. Comparison for electricity generation of each configuration 


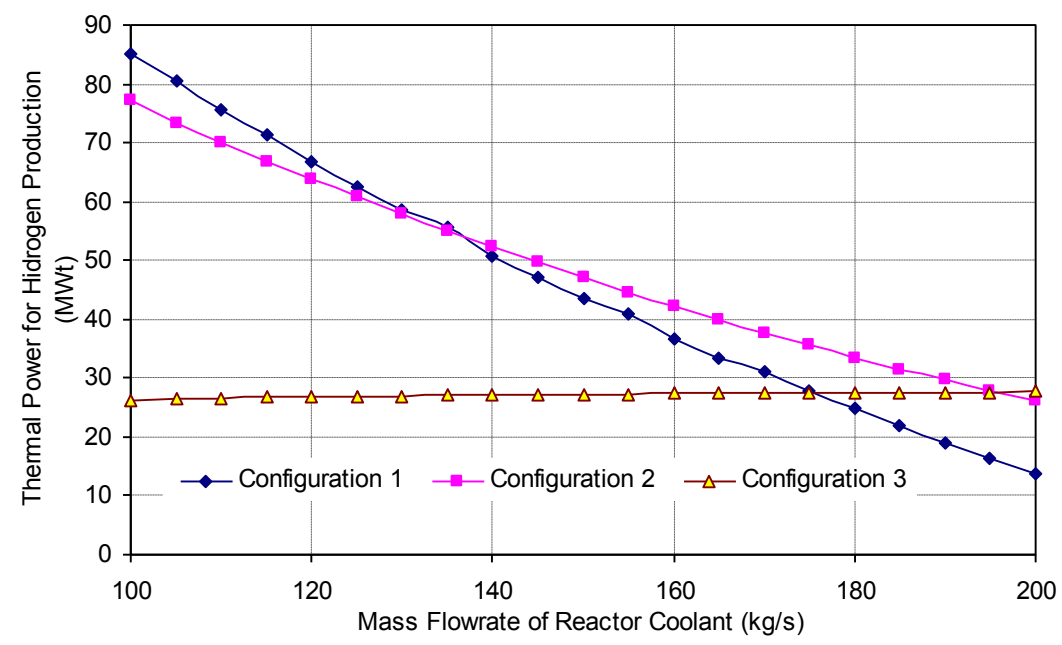

Figure 8. Comparison for hydrogen production of each configuration

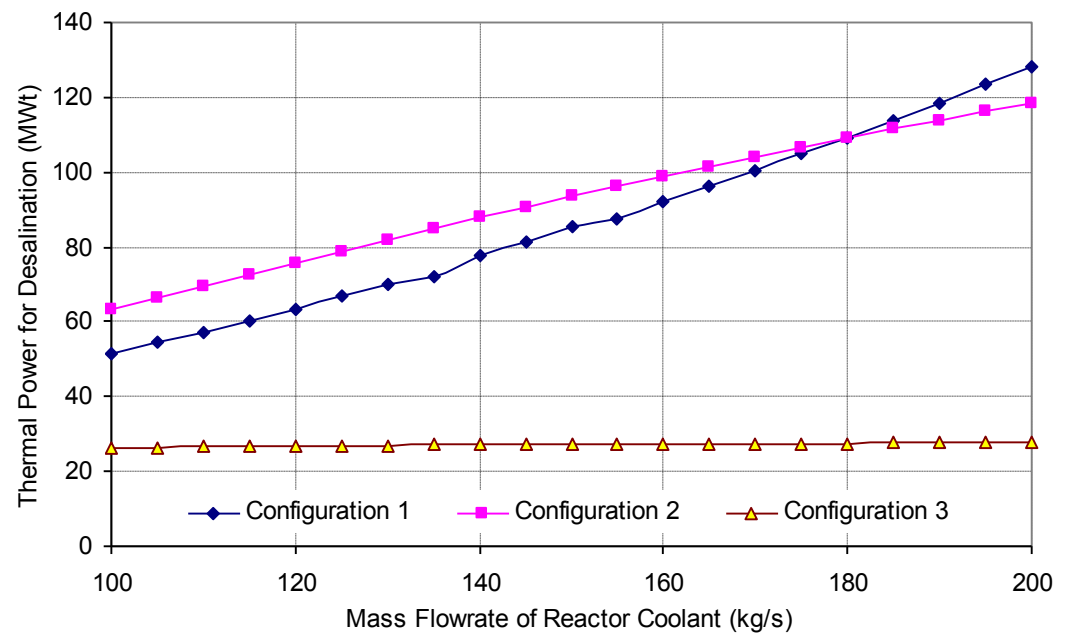

Figure 9. Comparison for desalination process of each configuration

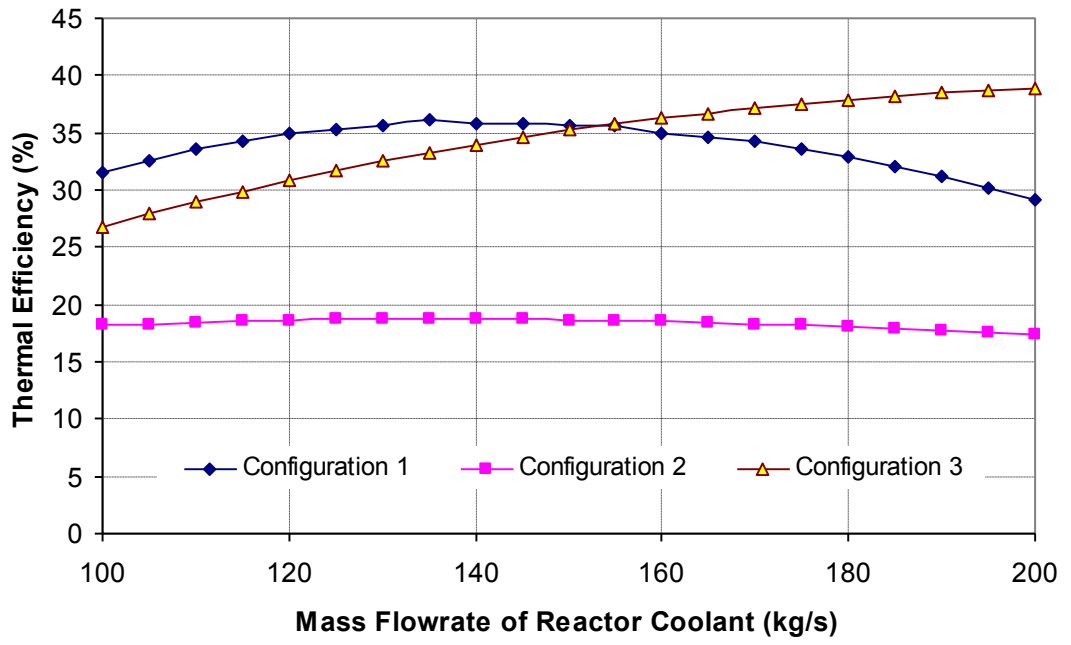

Figure 10. Comparison of Thermal Efficiency of each configuration 


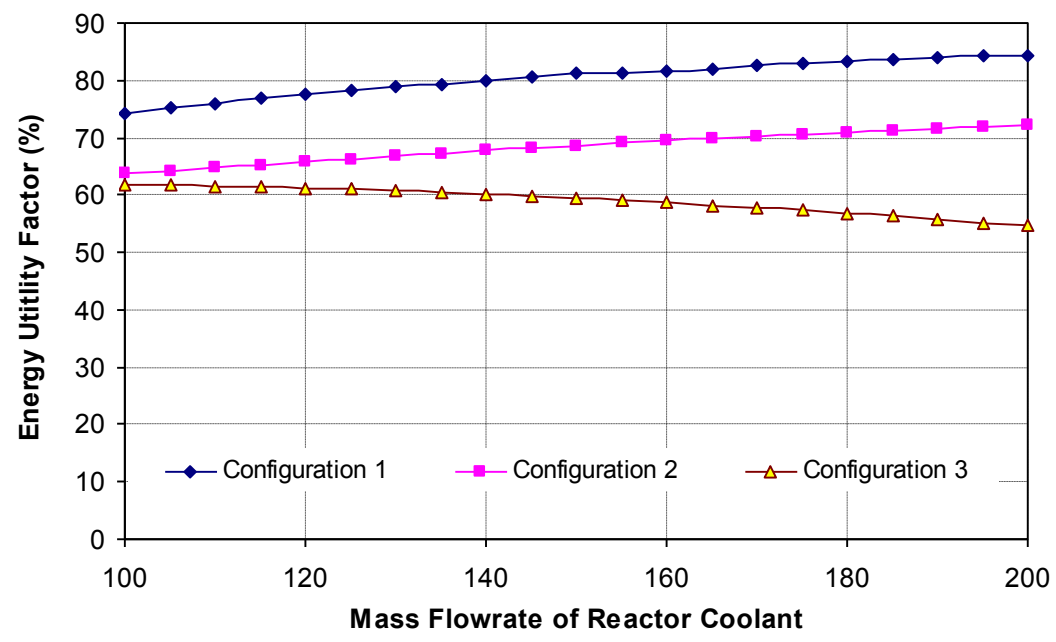

Figure 11. Comparison of Energy Utilization Factor of each configuration

In this conceptual design, there are three units of utilization, namely: for the production of hydrogen gas, for electricity generation and for seawater desalination process. EUF for electricity generation is a multiplication of thermal power for electricity generation with the electrical generator efficiency divided by the reactor thermal power. Thermal power for electricity generation represents the difference between the thermal expansion power turbine and thermal power for the compression in the compressor. In the simulation calculations, the efficiency of the electric generator is assumed to 98.66\% [21]. The results of these simulations, the value thermal efficiency and EUF is shown in Figure 10 and Figure 11.

EUF value for the production of hydrogen gas is the quotient of the thermal power transferred by IHX the reactor thermal power multiplied by the maximum efficiency for the production of hydrogen gas. The maximum efficiency that can be generated by a hydrogen gas production plant with steam methane reforming method is $65 \%$ [22]. Because of thermal power for the production of hydrogen gas that is transferred by IHX decreased due to the addition of the reactor coolant mass flow rate, the EUF for hydrogen gas production also decreased. This can be seen in Figure 11 that the increase in reactor coolant mass flow rate will result in a decrease EUF for the production of hydrogen gas. In the mass flow rate of the reactor coolant $145 \mathrm{~kg} / \mathrm{s}$, the value EUF for the production of hydrogen gas of each configuration are $12.22 \%, 12.90 \%$, and $14.61 \%$.

Seawater desalination process utilizing waste heat from the precooler is installed at the compressor inlet. The desalination process used for Low-Temperature method Multi-Effect Evaporation (LT-MEE) that can operate at a relatively low temperature of $70{ }^{\circ} \mathrm{C}$ [23]. With the LTMEE method, the seawater desalination process efficiency is $81.3 \%$ [23]. In the same way, as in the EUF calculations for the production of hydrogen gas, then the value EUF for seawater desalination process is the quotient of the thermal power transferred by the precooler reactor thermal power multiplied by the efficiency of the desalination process. Because the thermal power transferred by the precooler increases, the value of EUF for desalination has also increased. In the reactor coolant mass flow rate $145 \mathrm{~kg} / \mathrm{s}$, EUF value for seawater desalination of each configuration is $33.06 \%, 36.84 \%$, and $11.05 \%$.

EUF value is the result of a total of EUF value for each utilization of thermal energy. From Figure 11 shows that the total value EUF tends to rise with the increase in the mass flow rate of the reactor coolant through EUF value for hydrogen gas production declines. This is understandable because EUF value for power generation and desalination tends to rise with the increase in the mass flow rate of coolant. EUF value for electricity generation will be maximum in the reactor coolant mass flow rate of $145 \mathrm{~kg} / \mathrm{s}$. Assuming that the energy conversion systems are operated cogeneration RGTT200K coolant mass flow rate of $145 \mathrm{~kg} / \mathrm{s}$, then the values obtained EUF total of $80.63 \%$. In other words amounted to $80.63 \%$ of the thermal energy generated by the reactor can be used, or $19.37 \%$ of thermal energy is wasted to the environment. 
Thermal efficiency is the amount of thermal energy that can be used for electricity generation divided by the thermal power generated by the reactor. Thermal power for electricity generation represents the difference between the thermal power generated by the turbine and thermal power required by the compressor. Graph thermal efficiency for electricity generation as a function of the mass flow rate of the reactor coolant is shown in Figure 10. From Figure 10 indicated that the thermal efficiency for electricity generation increases with increasing mass flow rate of the reactor coolant and declined after reaching the thermal efficiency of $35.82 \%$. The highest thermal efficiency achieved in mass flow rate of the reactor coolant $145 \mathrm{~kg} / \mathrm{s}$. Comparison of the performance parameters from the three configuration design of energy conversion system RGTT200K shown in Table 2. As shown in Table 2, the highest thermal efficiency is $35.82 \%$ that can be produced from the first configuration. The highest value of EUF is also produced from the first configuration, that is $80.63 \%$. Thus, the first configuration be the best alternative for the design of cogeneration energy conversion systems Brayton cycle.

Table 2. Comparison of the performance parameters of the three configuration models.

\begin{tabular}{lccccc}
\hline & $\begin{array}{c}Q_{e} \\
(\mathrm{MWt})\end{array}$ & $\begin{array}{c}Q_{\text {des }} \\
(\mathrm{MWt})\end{array}$ & $\begin{array}{c}Q_{\text {hyd }} \\
(\mathrm{MWt})\end{array}$ & $\begin{array}{c}\eta \\
(\%)\end{array}$ & $\begin{array}{c}\text { EUF } \\
(\%)\end{array}$ \\
\hline $1^{\text {st }}$ configuration & 71.66 & 81.35 & 47.02 & 35.82 & 80.63 \\
$2^{\text {nd }}$ configuration & 37.39 & 90.66 & 49.63 & 18.69 & 68.17 \\
$3^{\text {th }}$ configuration & 69.24 & 27.21 & 27.21 & 34.59 & 59.79 \\
\hline
\end{tabular}

\section{CONCLUSION}

Three model configuration models of helium Brayton cycle for design energy conversion system RGTT200K have been investigated in order to maximize the thermal efficiency and the energy utilization factor. The first constraint determines the higher reactor coolant mass flow rate that the energy conversion system could supply the thermal energy at the temperature more than $800{ }^{\circ} \mathrm{C}$ to the hydrogen gas production. The simulation result shows that the first, second and third configuration models give the temperature of thermal energy more than $800{ }^{\circ} \mathrm{C}$ each at the reactor coolant mass flow rate of $145 \mathrm{~kg} / \mathrm{s}$. By comparing the performance parameter in the three configurations of Brayton cycle for RGTT200K cogeneration energy conversion systems, has to be found that the energy conversion system with a first configuration has the highest thermal efficiency and energy utilization factor (EUF). Thermal efficiency and energy utilization factor for the first configuration of the reactor coolant mass flow rate of $145 \mathrm{~kg} / \mathrm{s}$ is $35.82 \%$ and $80.63 \%$.

\section{ACKNOWLEDGMENT}

Our thanks to Ir. Tagor Malem Sembiring who helped author to complete this paper and provide time for discussion.

\section{REFERENCES}

1. Sophie Grape, et al. New perspectives on nuclear power - Generation IV nuclear energy systems to strengthen nuclear non-proliferation and support nuclear disarmament. Energy Policy 2014; 73:815-819.

2. Giorgio Locatelli, at al. Generation IV nuclear reactors: Current status and future prospects, Energy Policy 2013; 61:1503-1520.

3. Yan, X., et al. A hybrid HTGR system producing electricity, hydrogen and such other products as water demanded in the Middle East. Nuclear Engineering and Design 2014; 271:20-29. 
4. Mark F. Ruth, et al. Nuclear-renewable hybrid energy systems: Opportunities, interconnections, and needs. Energy Conversion and Management 2014; 78: 684-694.

5. Hiroyuki Sato. Assessment of the load-following capability of VHTR cogeneration systems. Annals of Nuclear Energy 2012; 49:33-40.

6. Gustavo Alonso, et al. Process heat cogeneration using a high-temperature reactor. Nuclear Engineering and Design 2014; 280:137-143.

7. Geschwindt, J.R., et al. Performance and optimization of an HTR cogeneration system. Nuclear Engineering and Design 2012; 251:297-300.

8. Colin F. McDonald. Power conversion system considerations for a high efficiency small modular nuclear gas turbine combined cycle power plant concept (NGTCC). Applied Thermal Engineering 2014; 73:82-103.

9. Po-Jui Li, et.al. A thermodynamic analysis of high-temperature gas-cooled reactors for optimal waste heat recovery and hydrogen production. Applied Energy 2012; 99:183-191.

10. Ign. Djoko Irianto. Thermodynamic Analysis for Optimization of Energy Conversion Systems RGTT200K. Proceedings of the Meeting and Scientific Presentations Basic Research Nuclear Science and Technology (PPI-PDIPTN), Yogyakarta, 2012.

11. Ign. Djoko Irianto. Analysis Of The Influence Of Coolant Mass Flow rate On The Performance Of RGTT200K Energy Conversion System. Proceeding of $18^{\text {th }}$ National Seminar on Safety and Technology of NPP and Nuclear Facility, Bandung 2012.

12. Heejin Cho, et al. Combined cooling, heating, and power: A review of performance improvement and optimization. Applied Energy 2014; 136:168-185.

13. E. Jannelli, et al. Thermodynamic performance assessment of a small size CCHP (combined cooling heating and power) system with numerical models. Energy 2014; 65:240-249.

14. Calin-Cristian Cormos. Hydrogen and power co-generation based on coal and biomass/solid wastes co-gasification with carbon capture and storage. International Journal of Hydrogen Energy 2012; 37:5637-5648.

15. Ana-Maria Cormos. Investigation of hydrogen and power co-generation based on direct coal chemical looping systems. International Journal of Hydrogen Energy 2014; 39:2067-2077.

16. Krishna Solanki, et al. Process Optimization Using CHEMCAD. International Journal of Futuristic Trends in Engineering and Technology 2014; 1: 47-51.

17. Lazaro Garcia, et al. Efficiency of the sulfur-iodine thermochemical water splitting process for hydrogen production based on ADS (accelerator driven system). Energy 2013; 57:469477.

18. Nesrin Demir. Hydrogen production via steam-methane reforming in a SOMBRERO fusion breeder with ceramic fuel particles. International Journal of hydrogen energy 2013 ; 38:853860 .

19. Mehmet F. Orhan, et al. Integrated hydrogen production options based on renewable and nuclear energy sources. Renewable and Sustainable Energy Reviews 2012; 16:6059-6082.

20. Mary O. Akpomiemie, et al. Retrofit of heat exchanger networks without topology modifications and additional heat transfer area. Applied Energy 2015; 159: 381-390.

21. M. Dandhang Purwadi. Analysis And Optimization Of The RGTT200K And RGTT200KT High-Temperature Gas-Cooled Reactor Systems. Jurnal Teknologi Reaktor Nuklir TRI DASA MEGA 2012; 14: 1-14.

22. Wenqiang Zhang, et al. Efficiency evaluation of high-temperature steam electrolytic systems coupled with different nuclear reactors. International Journal of hydrogen energy 2012; 37 : 12060-12068.

23. Yongqing Wang, et.al. Thermoeconomic Analysis of a Low-Temperature Multi-Effect Thermal Desalination System Coupled with an Absorption Heat Pump. Energy 2011; 36: $3878-3887$. 